\title{
Abdurrahman Wahid Structural Da'wah Activities
}

\author{
Awaludin Pimay $^{1 *}$ \& Agus Riyadi $^{2}$ \\ ${ }^{12}$ UIN Walisongo Semarang \\ *awaludinpimay@walisongo.ac.id
}

\begin{abstract}
This study aims to see how Gus Dur's da'wah activities with the position of President and what da'wah policies he made. This qualitative research uses historical methods and documentation as the primary data sources. The results showed that Gus Dur, who served as President from 20 October 1999 to $23 \mathrm{July}$ 2001, was based on a study of policies in the form of laws and regulations he signed, some of which included da'wah policies. These da'wah policies are related to Muslim worship (Keppres 8/2001, Presidential Decree 97/2000, Presidential Decree 22/2001), human rights (UU 1/2000, Presidential Decree 12/2001, Presidential Instruction 9/2000, Presidential Decree 1/2000, Presidential Decree No. 6/2000, Presidential Decree 69/2000), separatism (Presidential Decree 27/2000, Presidential Decree 75/2000, Presidential Decree 28/2000, Presidential Decree 47/2000), and corruption (PP 19/2000, PP 71/2000). Gus Dur used his power to preach democracy and humanity as the direction of his struggle.
\end{abstract}

Keywords: structural da'wah; laws and regulations; Abdurrahman Wabid.

\begin{abstract}
ABSTRAK
Penelitian ini bertujuan untuk melihat bagaimana aktivitas dakwah Gus Dur dengan jabatan Presiden serta kebijakan dakwah apa yang dibuatnya. Penelitian ini merupakan penelitian kualitatif dengan menggunakan metode historis dan dokumentasi sebagai sumber data utama. Hasil penelitian menunjukkan bahwa Gus Dur yang menjabat Presiden sejak 20 Oktober 1999 sampai 23 Juli 2001 berdasarkan kajian terhadap kebijakan berupa peraturan perundang-undangan yang ditandatangani olehnya, beberapa diantaranya termasuk kebijakan dakwah. Kebijakan dakwah tersebut terkait tentang ibadah umat Islam (Keppres 8/2001, Keppres 97/2000, Keppres 22/2001), hak asasi manusia (UU 1/2000, Keppres 12/2001, Inpres 9/2000, Inpres 1/2000, Keppres 6/2000, Keppres 69/2000), separatisme (Keppres 27/2000, Keppres 75/2000, Keppres 28/2000, Keppres 47/2000), dan korupsi (PP 19/2000, PP 71/2000). Artinya, Gus Dur menggunakan kekuasaannya untuk berdakwah dengan demokrasi dan kemanusiaan sebagai arah perjuangannya.
\end{abstract}

Kata kunci: dakwah struktural; peraturan perundang-undangan; Abdurrahman Wahid.

Received: Oktober 2021. Accepted: November 2021. Published: Desember 2021. 257 


\section{INTRODUCTION}

An excellent Islamic ideology will forever remain an unrealized idea and ideal if no people propagate it. One of the cores of the Islamic da'wah movement lies in the preacher. Considering how strategic the role of dai in da'wah is, many dai's qualifications are needed to support da'wah's success (Aziz, 2016: 216). Assiba'i explained the criteria for the ideal preacher as the Prophet Muhammad, namely being born of good and noble offspring, having high intelligence and sensitivity, having a solid life history, having a high sense of humanity, living with good business results, having experience and socializing wide area, and obedient to worship (Assiba'i, 1997: 43-44). K.H. Abdurrahman Wahid, according to Rosidi, is a preacher who meets the criteria as described by Assiba'i, namely integrity, knowledge, and has the ability and qualified experience (Rosidi, 2013: 485486).

However, later, Gus Dur was called a da'wah expert who explicitly put his thoughts in da'wah science works. Gus Dur is better known as a Muslim scholar whose thoughts are dynamic, challenging, and full of 'surprises,' as well as quirky, vocal, and controversial. Emha Ainun Najib calls him a 'crazy person,' namely, a person who initiates what other people do not think about and imagines what other people do not (Wahid, 1999: 17-18).

Gus Dur's struggle began before he was at NU when he was at NU, Non-Governmental Organizations (NGOs), the National Awakening Party (PKB), as well as when he was President and after he was no longer in office (Rifa'i, 2017: 57-86). Gus Dur is a figure who consistently fights for democracy in Indonesia. The concept of indigenization of Islam which was initiated by him both through writings (works in the form of articles/books) and movements (his work in the Nahdlatul Ulama/NU organization), became evidence that Gus Dur was indeed an active figure calling for goodness for changes for the better. This is in line with da'wah's nature, namely activities and efforts to change people from bad situations to be better (Aziz, 2016: 10). Change towards a life based on submission to achieve happiness in this world and the hereafter (Kusnawan \& Rustandi, 2021).

According to Gus Dur, Islamic da'wah must be held to uphold or maintain the values of Islamic universalism to the community as the last and perfect heavenly religion (Wahid, 2007: 4-5). Maintaining means 
maintaining and caring for existing Islamic values so that they remain upright and protect from threats that damage or disturb. Gus Dur emphasized non-textual values, therefore the function of Islamic teachings (through their fundamental values) as social ethics to guide the course of social and state life to achieve prosperity in life (Riyadi, 2021: 2). Islam has to prosper human life by developing social ethics through the most effective form of society called the state or outside the state (Wahid, 2007: 75-77).

The capital of religious belief alone is not enough as a provision for preaching. Power is also needed to oversee the journey of Amar makruf nahi munkar (Mahfud, 2015: vii). Rasulullah saw. In this regard, it is said

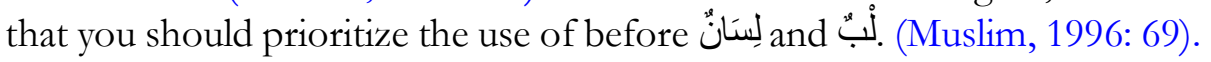
That is, you should prioritize actions before the speech.

Based on the use of power, da'wah can be categorized into cultural da'wah when its activities are not with power (Sulthon, 2003: 27). The second form, structural da'wah, take advantage of power as a medium of da'wah. This second form is considered to be quite potential to achieve da'wah's success, but this area is still empty of enthusiasts. The causes of the lack of structural da'i include polemics (at the level of action) originating from the heterogeneity of the da'i's views on the concept of structural da'wah, thus giving birth to various structural da'wah objectives. For this reason, studies on structural da'wah need to be reproduced so that da'i are more open to the area of da'wah with this power.

Power is not the only da'wah tool that guarantees da'wah's success, but power can be used as an effective da'wah medium. Historically, the Prophet Muhammad. Proving the effectiveness of da'wah through power, namely in the Medina period. This period was seen as strengthening the spread of the message of Islam more broadly than da'wah activities in the Mecca period. In the Medina period, the Prophet Muhammad implemented Islam in the main joints of people's lives. In this period, too, Islam became the foundation in strengthening the foundation of the state (Rustandi \& Sahidin, 2019).

Research on structural da'wah has been done before. For example, Farhan (2014) studied structural da'wah on the linguistic aspect. In the perspective of dramaturgy, structural da'wah language is conveyed through verbal and nonverbal messages. Another research was carried out by Tata Sukayat (2015), who took the prototype of the City of Bandung in analyzing structural da'wah through the application of the Bandung Religious public 
policy. It is concluded that the structural da'wah in Bandung Religious reflects the internalization and transformation of Islamic values without the need to label Islamic law.

Research by Bambang Subandi (2019) analyzes the form of structural da'wah through disseminating messages with the theme of religious nationalism. In his research, it is concluded that religious nationalism is a form of structural da'wah appropriate for a plural and multicultural Indonesian society. Another study that took cases in several cities was carried out by Syahruddin (2020), who took the locus of the city of Palopo. Muhammad Misbahul Huda (2020) observes the structural da'wah method of a Kiai in a boarding school. In this case, KH. Ahmad Fauzan becomes a role model in analyzing this phenomenon. and research by Alfan Arifuddin and Syarif Ahmad Muzammil (2020) who took the object of study in the Pontianak Kadiriyah Sultanate. This was also done by Rasyidah (2017), who examined structural da'wah in Malaysia.

The studies above can be used as a basis for developing a discussion on structural da'wah. This study is intriguing to balance the thoughts and movements of Islamic da'wah that utilizes the strategic spaces of the state as a medium of da'wah. The researcher believes that the compatibility between cultural and structural da'wah is part of building awareness and harmonization of the spread of Islamic messages in the concept of rahmatan lil alamin. At this point, the researcher considers that the structural da'wah movement is carried out to strengthen the internalization of Islamic teachings and transform each object of da'wah to conform to the values of Islamic teachings both at the fardiyyah, ummah, and daulah levels. One of the prototypes of structural da'wah that is interesting to study is the idea and movement of KH's da'wah. Abdurrahman Wahid (Gus Dur) utilizes state policies as an effective propaganda medium.

According to Gus Dur, the struggle of Muslims does not have to prioritize the way to enter and control the government bureaucracy. Massive improvement in the life of the lower layers has become a necessity (Wahid, 1997: 251). Gus Dur had fought through power when he was officially inaugurated as President of the Republic of Indonesia on October 20, 1999. The question is whether Gus Dur used his position as the holder of power over the State of Indonesia to preach or not. Gus Dur's ascension to become President is a beautiful Muslim politics (Ilaihi, 2007: 200). Nasihun Amin calls it the "Republic of Santri". The President is a Kiai (Gus Dur), the chairman of the MPR is a Muslim intellectual (Amin Rais), even 
the chairman of the DPR has no doubts about his Islamic faith (Akbar Tandjung). Assemblies, councils, factions, and other key positions are also filled mainly by Kiai or figures with religious education backgrounds (formal and non-formal). The political position at that time could be said to be strategic, but Indonesia still has not changed (Amin, 2007: 186-187).

The leadership journey of the President and Kiai is one of the valuable assets in the development of da'wah (Pimay, 2006: 44-46). This research is to discover what Gus Dur did in realizing his structural missionary goals. The purpose of da'wah is directed at the goals of the unitary state of the Republic of Indonesia, as stated in the fourth paragraph of the Preamble to the 1945 Constitution, "to protect the entire Indonesian nation and the entire homeland of Indonesia and to promote public welfare, educate the nation's life, and participate in implementing world order based on independence, eternal peace, and social justice." The research object is focused on da'wah policy, considering that policy is a government tool to regulate many things related to what is done and what is not done (Dye, 2014: 3).

This research is qualitative, casuistic, related to the discussion of Gus Dur's structural da'wah activities (Creswell, 2014: 4). Since the da'wah process studied occurred in the past, the historical method was used, namely studying the history of da'wah to formulate essential things about da'wah's journey (Abdullah, 2018: 46). The main highlight of historical da'wah research is the forms of da'wah carried out in the past and the present, which have close links with da'wah in the past (Aziz, 2016: 215) in this case, Gus Dur's structural da'wah activities.

Data collection techniques through documentation. Documentation techniques are the primary way to obtain data on Gus Dur's past structural da'wah. The research data was obtained by downloading legal product documents through the government's official website, namely http://peraturan.go.id, which is the official information channel for the Ministry of Law and Human Rights of the Republic of Indonesia, as well as the official website http://jdihn.go.id/ which the Indonesian National Law Development Agency manages. If neither of them is found, then another site owned by the Indonesian government is used. 


\section{RESULTS AND DISCUSSION}

\section{Genealogy and Personality of Abdurrahman Wahid}

His birth name is Abdurrahman ad-Dakhil ('the conqueror'), the first son of Wahid Hasyim and Siti Solikhah. Genealogy of father and mother, both from Soichah bint Abd. Jabar bin Ahmad bin Prince Sambo bin Prince Banawa bin Joko Tingkir (Karebet) bin Brawijaya VI (Lembu Peteng). The paternal line, Abdurrahman Wahid bin Wahid Hasyim bin Muhammad Hasyim Asy'ari bin Winih bint Lajjinah bint Soichah. Mother line, Abdurrahman Wahid bin Solikhah bint Nyai Bisri Sansuri bint Hasbullah bin Fatimah bint Soichah (Rifai, 2017: 25).

Abdurrahman Wahid was born in Denanyar, Jombang, East Java, on the eighth month of the Hijri calendar. To be precise, on the fourth day, namely 4 Sya'ban 1359 or September 7, 1940, at a boarding school owned by his maternal grandfather, Kiai Bisri Syansuri. For some reason, his birth date was recorded as of September 4, 1940, as the date usually commemorated as the birthday of his lifetime (Barton, 2011: 25). Like the pesantren culture, Abdurrahman Wahid, who incidentally is the son of a Kiai, so is familiarly called 'Gus,' Gus Dur.

Little Gus Dur grew and developed in the pesantren environment. Gus Dur, when he was about four years old, around the end of 1944, accompanied his father, Wahid Hasyim, to Jakarta. They live in a neighborhood crowded with businesses, professionals, and politicians. While in Jakarta, Gus Dur was often with and accompanied his father, who served as Minister of Religion and went to meetings (Barton, 2011: 43). After his father died, as the eldest son, he was expected to follow in his footsteps.

Gus Dur studied with K.H. Ali Ma'shum at the al-Munawwir Krapyak Islamic Boarding School, Yogyakarta. Gus Dur finished elementary school in 1954 and continued at the Junior Economics High School (SMEP) until he graduated in 1957. After that, he started studying at Islamic boarding schools. Tegalrejo Magelang was nurtured by Kiai Khudori until the middle of 1959. While in Jogja and Magelang, he began to devour readings about European social thought and English, French, Russian novels, in which humanity was the theme that caught his attention. Gus Dur continued to study until 1963 under Kiai Wahab Chasbullah at Islamic boarding school. Jombang rice pond. This madrasa belonging to the pesantren is where Gus Dur started teaching. This is also where Gus 
Dur met Nuriyah, who would later become his wife.

In November 1963, with a scholarship from the Ministry of Religion, Gus Dur continued his education at the Syari'ah Faculty, Al-Azhar University, Cairo, Egypt. While in Cairo, Gus Dur served as a student leader at the Indonesian Embassy. For some reason, Gus Dur did not finish his studies, then moved to the Faculty of Adab, Department of Arabic Literature, Baghdad University, Iraq, in 1966. Gus Dur served as chairman of the Indonesian Student Association. After completing his studies in the mid-1970s, he chose the Netherlands, Germany, and France as a place of study. Due to specific reasons, in mid-1971, he returned to his homeland without continuing his studies (Barton, 2011: 87-112).

Gus Dur married on July 11, 1968 to Sinta Nuriyah. They have four daughters, first Alissa Qotrunnada Munawaroh, second Zannuba Arifah Chafsoh, third Annita Hayatunnufus, and lastly Inayah Wulandari. The day before the 27th birthday of his youngest daughter, Gus Dur died in Jakarta on Wednesday, December 30, 2009 (Rifai, 2017: 41-49).

This family background and social life led Gus Dur to have a holistic and comprehensive thought in interpreting Islam as a way of life in various aspects of life. His educational background makes Gus Dur a person who respects differences. Gus Dur became a figure who displayed the attitudes and views of a Muslim's life as a person, household leader, social leader, and state leader. Gus Dur's leap of thought was experienced because his deepening in contact with various traditions, starting from traditionalism in Islamic boarding schools, Islamism, Arab nationalism and socialism, Eastern and Islamic philosophy, as well as Western philosophy and social science, had greatly influenced and shaped the eclectic character of Gus Dur's thought ('Taufani, 2018).

The intersection with heterogeneous cultural diversity made Gus Dur an open and tolerant person. In this case, Gus Dur strengthened national plurality with the concept of diversity and religiosity. On the one hand, Gus Dur became a person who believed in his religion fundamentally and strongly. On the other hand, Gus Dur accommodated the philosophical values of the state contained in Pancasila (Barton, 2011).

This has become Gus Dur's capital in unraveling the path of structural transformation of Islamic da'wah. Where Gus Dur utilizes the strategic space of the state as an effort to strengthen Islamic values in the context of the state, this was done by Gus Dur through the formulation and stipulation of public policies, which were poured into various laws and 
regulations in the form of Laws, Perppu, PP, Presidential Decrees, and Presidential Instructions.

\section{Structural Da'wah Activities Through Da'wah Policies}

The mandate of the Qur'an in Surah Ali 'Imran/3: 104 regarding the obligation to preach is the basis that one of the functions of the government is as an organizer or executor of da'wah (Riyadi, 2014: 113). The political aspect of a crucial position in the government should be a field for da'wah. Politics is closely related to decision-making and policymaking in a country, especially a democratic country like Indonesia.

Political power, concerning da'wah and the religion of Islam, has two sides at once. Politics can be a tool to accommodate the values of Islamic teachings in a policy. Politics can also be a threat that can give birth to policies not under Islamic law, likewise with the continuity of da'wah. Politics can sometimes be a tool of da'wah that facilitates the delivery of da'wah messages to recipients. Politics is simultaneously an obstacle to the continuity of da'wah with the power of prohibition that can be made.

Between political power and da'wah, they should go hand in hand in one view of goals that are not contradictory. Da'wah actors would be better off if they became political actors or leaders who can determine state policy. Such a da'i has direct control over the various policies formed so that the preacher can move with the action, not only with words or heart.

According to Gus Dur, religious leaders should play a more dominant role as leaders in society. They should prioritize the welfare of the people they lead. The success of a leader is measured by the effectiveness or benefits of their policies or actions for the benefit of the community (tașarruf al-imām 'alà ar-rä'iyyati manütun bil maṣlahah) (Wahid, 2006: 276).

The interests of the community championed by the leader are the general public as a whole, as did President Gus Dur. The da'wah policies taken are not only fighting for the group's interests, ethnicity, or religion, namely Islam. The values that became the basis of Gus Dur's struggle were the values of monotheism, humanity, justice, equality, liberation, simplicity, brotherhood, chivalry, and local wisdom. These values are manifested in the form of da'wah policies.

Gus Dur's policies in accommodating the worship interests of Muslims, policies in upholding human rights, policies in fighting for unity and integrity by fighting separatism, as well as his policies in eradicating the 
theft of state wealth or corruption, are tangible results as a result of his power as President of the Republic of Indonesia. This policy is proof that Gus Dur used peace and humanity in his role as a messenger of Islamic teachings with a position of power as President.

Structural da'wah activities through da'wah policies can be understood as public policies that partially or wholly regulate/relate to da'wah's interests in particular or the religion of Islam in general and impact the religious life of Muslims. Gus Dur made his da'wah activities through da'wah policies by utilizing his power as President in legislation, namely regulating statutory regulations as a medium for preaching. Gus Dur's da'wah policy as a form of structural da'wah activity consisted of regulations in the form of laws, government regulations in place of laws, government regulations, presidential decrees, and additional presidential instructions.

Structural da'wah is an effort to transform Islamic values into the public sphere. Practically, efforts are made through compromise and negotiations that can bring win-win solutions without impacting conflict or even violence. Structural da'wah is a strategic transformation that can display the image of Islam as a universal and just teaching, not only internally for Muslims but also all human groups (Sukayat, 2015). This is what Gus Dur did while serving as President of the Republic of Indonesia in diffusing Islamic values in the state space.

Universal Islamic values become the material for da'wah in the public policy space. The symbiotic paradigm of da'wah is seen as strengthening the efforts of Amar maruf nahi munkar. The state and nation are fundamental structural da'wah institutions and significantly impact the dissemination of Islam in Indonesia (Subandi, 2019). This view states that the state is a space for sowing nationalism, wherein the context of da'wah, religious nationalism becomes a strategy in mapping out structural da'wah (Calhoun, 1997; Sekulic, Massey, \& Hodson, 2006).

\section{Structural Da'wah Strategy Through Legislation}

Strategy is understood as all efforts to deal with specific goals to obtain maximum results. Da'wah strategy means an overall approach related to the implementation of ideas or ideas and planning and implementing da'wah activities. Structural da'wah strategy here means planning containing a series of Gus Dur's da'wah activities designed to achieve structural da'wah goals. In this case, the strategy relates to efforts to carry out Islamic da'wah activities that are planned, measured, and directed. The 
systems approach views da'wah as a structure that includes systemic components that are bound, connected, and networked (Rustandi \& Hanifah, 2019; Kusnawan \& Rustandi, 2021).

Abdurrahman Wahid's structural propaganda strategy with the position of President of the Republic of Indonesia can be reviewed based on Article 4 Paragraph (1) of the 1945 Constitution, stating that "The President of the Republic of Indonesia holds governmental power according to the Constitution." The President is the head of government in the Republic of Indonesia.

The government is known to contain two aspects, namely formal and material. Government in the formal sense contains the power to regulate and the power to decide, while in the material sense, it contains elements of governing and implementing elements. This regulatory power implies that the government has the power to form regulations. The President, the holder of government power who has regulatory power, has the right to form laws and regulations needed to administer the government (Soeprapto, 2002: 61-63).

Legislation is the only regulation with legal force and binding with a broad/general scope. This can be reviewed in the Legislation according to Law Number 15 of 2019 concerning Amendments to Law Number 12 of 2011. The types and hierarchies of the laws and regulations in effect during the Gus Dur era were different from today. Items of Presidential Decree that were in effect during the Gus Dur era have now been changed to Presidential Regulations. Regional Regulations are divided into Provincial Regulations and Regency/City Perda. Hierarchy of Legislation in the era of President Gus Dur based on MPR Decree Number III/MPR/2000, namely the 1945 Constitution, MPR Decrees, Laws, Government Regulations instead of Laws, Government Regulations, Presidential Decrees, and Regional Regulations.

The existing laws and regulations under the authority of the President as the executor of the government based on the provisions in the 1945 Constitution consist of Laws/UUs (Article 5 Paragraph (1): "The President has the right to submit Draft Laws to the House of Representatives"), Government Regulations Substitute Law/Perppu (Article 22 Paragraph (1): "In the case of compelling urgency, the President has the right to stipulate a Government Regulation instead of Law"), Government Regulation/PP (Article 5 Paragraph (2): "The President determines Government Regulations to carry out the Law properly"), as well as Presidential 
Decrees/Keppres or Presidential Regulations/Perpres (Article 4 Paragraph (1): "The President of the Republic of Indonesia holds governmental power according to the Constitution").

All da'i cannot carry out structural da'wah strategies through statutory regulations. Only certain da'i can be directly involved in making regulations and have the power to ratify, revoke, or cancel these regulations, including the President. As the fourth President of the Republic of Indonesia, Gus Dur is considered to have used his power to preach, one of which was to use his power in the field of legislation to regulate religious life and the interests of Muslims, as well as to spread the message of da'wah or Islamic teachings.

Da'wah through Legislation can be categorized as da'wah through writing (bil kitābah) because the form of the regulation is written on the State Gazette paper. Statutory regulation is divided into four major parts: naming, opening, body, and closing. First, naming, containing a brief description of the contents of the statutory regulations preceded by the mention of the type, number, and year of formation, and a short sentence that reflects the contents of the statutory regulations. Second, the preamble consists of three main parts: the considerations (reasons/considerations), the legal basis for the formation, and the Legislation title.

Third, the body contains the formulations, which are the content of the legislation consisting of chapters, articles (units of reference), and paragraphs. Each body contains general provisions, regulated material provisions, criminal provisions, transitional provisions, and closing provisions. Fourth, closing is the final part of a statutory regulation consisting of the formulation of promulgation orders, ratification, promulgation, signing of the authorized official, and mention of the relevant State Gazette (Soeprapto, 2002: 157-167).

Regarding the regulations, Rasulullah saw. A Muslim leader with power has used regulations as a medium for Islamic struggles, such as the example of regulations reflected in the Hudaibiyah Agreement of 628 AD. This agreement regulates the relationship between Muslims and the Quraysh. The wisdom is that the da'wah of the Prophet is getting more comprehensive to all corners of the world (Fatimah, 2009: 75). Structural da'wah through statutory regulations is a necessity that is legal to do as long as you are able and have the opportunity.

Through this regulation, Da'wah is carried out to build negotiations and strategies for state da'wah. Historically, the concept of negotiation 
carried out by the Prophet Muhammad in the phase of the Islamic da'wah struggle was carried out to strengthen the diffusion of Islamic values. The historical perspective views the diversity of negotiating charters such as the Hudaibiyyah agreement and the Medina Charter as authentic evidence of the da'wah bil Kitabah carried out by the Prophet Muhammad in mapping the message of Islam (Rustandi \& Sahidin, 2019). This is what strengthens the Prophet Muhammad's position as the leader of the people's preference. Leaders who lead their groups and are human leaders who are role models for anyone.

\section{Structural Da'wah Methods Through Da'wah Policies}

The method is a continuation of the strategy, which is a method that can be used to implement a strategy in order to facilitate the implementation of an activity in order to achieve the specified goals. The da'wah method, in this case, is the fastest and most appropriate way to implement the da'wah strategy. The da'wah method according to the Qur'an in Surah AnNahl verse 125 consists of (a) the method of wisdom, namely preaching with wisdom; (b) the lecture method, namely preaching with good words or advice; and (c) the method of debate or discussion, namely preaching with a two-way communication method between the da'i and the madh ' $\bar{u}$. Another method, namely through example (dakwah bil hal) to preach with good actions/deeds exemplified by the preacher (Riyadi, 2020: 147).

Gus Dur's structural da'wah method was carried out by formulating laws and regulations with his position as head of government (President). This is done by making or passing laws stipulating Perppu, PP, and Presidential Decrees. Gus Dur, during his tenure as President of the Republic of Indonesia from October 20, 1999, to July 23, 2001, as far as investigations have been found, has formed many 593 statutory regulations and 17 other regulations.

The first regulation is in law, totaling 51 laws. Gus Dur ratified 38 laws in 2000, namely Laws Number 1 to Number 38 of 2000. 13 laws were enacted in 2001, namely Laws Number 1 to Number 13 of 2001. These laws constitute policies in law, economy, politics, socio-culture, and regional development.

The second regulation is in Government Regulations instead of Law, namely three Perppu signed by Gus Dur in 2000. The Perppu are Perppu Numbers 1 to Number 3 of 2000. The three Perppu are policies that regulate the economic sector. 
The third regulation is a Government Regulation of 219 PP. Gus Dur enacted 5 PPs in 1999, namely PP No. 95 to No. 99 of 1999. A total of 155 PPs were enacted in 2000, namely PP No. 1 to No. 155 of 2000. 59 PPs were enacted in 2001, namely PP No. 1 to No. 59 of 2001. All these PPs regulate the fields of law, economy, politics, education, socio-culture, regional development, and natural resources, and the environment.

The fourth regulation is a Presidential Decree of 320 Keppres. Gus Dur issued 47 Presidential Decrees in 1999, namely Presidential Decrees No. 132 to No. 178 of 1999. A total of 183 Presidential Decrees were issued in 2000, consisting of Presidential Decrees No. 1 to No. 181 of 2000 and Presidential Decrees No. 241/M and No. 289/M of 2000. 90 Presidential Decrees were issued in 2001; namely, Presidential Decrees Number 1 to 90 of 2001. These Presidential Decrees regulate all fields of development, namely law, economy, politics, religion, education, social culture, regional development, natural resources, the environment, and defense and security.

A total of 17 regulations in the form of Presidential Instructions were issued by Gus Dur, namely two Presidential Instructions in 1999 (Inpres Number 15 and Number 16 the Year 1999). 9 Presidential Instructions were issued in 2000, namely Presidential Instruction No. 1 to No. 9 of 2000. 6 Presidential Instructions were issued in 2001, namely Presidential Instruction No. 1 to No. 6 of 2001. These Presidential Instructions are policies in the economy, politics, socio-culture, natural resources, and the environment. Life.

A total of 593 laws and regulations were formed by Gus Dur, primarily regulating problems in the economic sector (208 regulations) and politics (212 regulations). This is undeniable, considering that Gus Dur's reign was a period of transition from the old order to reform. Not to mention domestic problems related to state administration and security.

Gus Dur's structural da'wah method through da'wah policy, in this case, means making laws and regulations that impact or regulate the religious life of Muslims or contain the interests of Muslims and the Islamic religion. The da'wah policy regulates matters of worship, namely related to the implementation of zakat and hajj and matters of muamalah.

Gus Dur's other da'wah policy was the implementation of da'wah messages to address various issues facing his government, such as democratization, human rights, separatism, and corruption. The da'wah policies made are contained in various types of statutory regulations such as laws, government regulations, presidential decrees, presidential 
instructions, and other laws.

\section{Da'wah Techniques through Laws, Perppu, PP, Presidential Decrees, and Presidential Instructions}

Technique means method or system of doing something (KBBI). Here, the da'wah technique means the implementation steps or how to implement Gus Dur's structural da'wah method. A technique is a practical explanation of a concept called a method. Da'wah techniques depend on da'wah methods, such as the lecture method, preparation, delivery, and closing techniques.

Gus Dur's structural da'wah technique with the da'wah policy method consists of stages or procedures that a President must carry out in making laws and regulations as applicable rules. Both Laws, Perppu, PP, Presidential Decrees, and Presidential Instructions, each have different manufacturing procedures.

First, the Law is a statutory regulation established by the DPR with the joint approval of the President. This is stated in Law Number 15 of 2019, Amendments to Law Number 12 of 2011 concerning the Establishment of Legislation, Article 1, Number 3. Laws are the only regulations that the President cannot decide unilaterally. This means that there must be approval from another party, namely the DPR. In terms of making laws, the President shares authority with the legislature. The core stages of law formation consist of three main processes: preparing the Draft Law by the President of the DPR/DPD and obtaining the approval of the DPR. The process of ratification by the President was followed by promulgation by the Ministry of Law and Human Rights (Soeprapto, 2002: 134).

Second, Government Regulations instead of Laws, namely Legislations established by the President in compelling urgency. Law Number 15 of 2019, Amendments to Law Number 12 of 2011 concerning the Establishment of Legislation, Article 1, Number 4 references in this matter. Forming a Perppu consists of two stages, namely the stage of preparing the Draft Perppu and the stage of ratification by the President followed by promulgation by the Ministry of Law and Human Rights. The initiative to make the Draft Perppu can be from the Minister, the Head of a Non-Ministerial Government Institution, or the President's initiative. Due to the temporary validity period of the Perppu, after being promulgated, the Perppu must immediately be submitted to the DPR in the 
subsequent trial for approval. If the DPR agrees, the Perppu will be promulgated into law. If the DPR refuses, the Perppu will be revoked or no longer valid. As in Law Number 15 of 2019, Amendments to Law Number 12 of 2011 concerning the Establishment of Legislation, Article 52.

Third, Government Regulations, namely Legislations decided by the President to carry out the Law as it should be. As in Law Number 15 of 2019, Amendments to Law Number 12 of 2011 concerning Formation of Legislation, Article 1, Number 5. The process of forming a PP consists of two stages: making the Draft PP and ratification by the President and by the Ministry of Law and Human Rights. Before the President stipulates that the Draft PP becomes a PP, a response is first requested from the relevant authorized officials. After being assessed as reasonable and appropriate, the President will then sign it as a sign of ratification (Soeprapto, 2002: 154).

Fourth, a Presidential Decree that is regulating is made by the President to carry out his functions and duties in the form of regulating the implementation of state administration and government administration. This can be reviewed in the Decree of the People's Consultative Assembly Number III/MPR/2000, Sources of Law and Order of Legislation, Article 3 Paragraph (6). The Presidential Decree is a statutory regulation that is the authority of the President in running the government. Forming the Presidential Decree consists of two stages, namely the stage of making the Draft Presidential Decree and the stage of ratification by the President and the promulgation by the Ministry of Law and Human Rights (Soeprapto, 2002: 156).

Fifth, Presidential Instructions, namely orders from superiors to individual subordinates, concrete, and once completed (final, einmahlig) so that they cannot be classified in-laws and regulations (wetgeving) or policy regulations (beleidsregel, pseudo-wetgeving). The Presidential Instruction cannot bind everyone as statutory regulations. However, it can only bind Government officials whose position is under the President or assistants for implementing government administration, such as Ministers and Heads of Non-Departmental Government Institutions (Soeprapto, 2005: 6).

Gus Dur's technique for implementing the da'wah method through da'wah policies in the form of statutory regulations is to go through the procedural stages that the President must carry out in forming statutory regulations. The rules for forming Legislation in the era of President Gus Dur were set based on the procedures in Presidential Instruction No. 
15/1970, which contained guidelines for the preparation of Draft Laws and Draft Government Regulations.

During the Gus Dur administration, the Presidential Decree was still a legal product with the sixth legal force in the Indonesian laws and regulations hierarchy based on MPR Decree Number III/MPR/2000 concerning Legal Sources and Ordering Legislation. The hierarchy of laws and regulations based on Article 2 of MPR Decree Number III/MPR/2000 is the 1945 Constitution; MPR Decree; Constitution; Government Regulation instead of Law; Government regulations; Presidential decree; and Regional Regulations. This means that a President has the opportunity to use his authority to the maximum extent possible to realize the goals of the state and the interests of the Indonesian people. President Gus Dur was among those who took this step, which during his tenure established 320 Presidential Decrees for various fields of development, including the field of religion, which accommodates the interests of Muslims in matters of worship and muamalah.

Based on Article 7 Paragraph (1) of Law Number 12 of 2011 concerning the Establishment of Legislative Regulations, Presidential Decrees are no longer included in Legislation, replaced by Presidential Regulations (Perpres). Types and hierarchy of laws and regulations based on Article 7 Paragraph (1) of Law Number 12 of 2011 concerning the Formation of Legislations consisting of the 1945 Constitution, MPR Decrees, Laws, Laws/Government Regulations instead of Laws, Government Regulations, Presidential Regulations, Provincial Regulations, and Regency/City Regional Regulations.

Presidential Decrees are legal norms that are concrete, specific, or individual, once completed. The contents of the presidential decree generally apply to certain parties or persons mentioned in the presidential decree only. Perpres is recognized as a statutory regulation stipulated by the President to carry out orders in higher laws and regulations or to carry out government powers. The position of the Presidential Decree in several respects based on Article 100 of Law 12/2011 can be similar to that of the Presidential Decree, namely when the Presidential Decree that existed before the enactment of Law 12/2011 and is regulatory is still interpreted as regulation as long as it does not conflict with the Law.

The binding legal force is one of the plus points for making the Legislation a structural da'wah path. The higher the position or the power of regulations before the law, of course, the better and more effective to 
accommodate the message of da'wah in it. Dai or the fundamental preacher in this matter is the President himself who holds a position or position that is quite strategic regarding the formation of laws and regulations.

\section{Abdurrahman Wahid Structural Da'wah Tactics}

Da'wah tactics are Gus Dur's style in applying structural da'wah techniques and methods. Each preacher certainly has a different tactic, meaning that it is flexible depending on the recipient of the da'wah being faced, the circumstances, and other internal and external factors to the preacher. The same method may be applied with different tactics by different preachers. The Qur'an explains dichotomous tactics, tactics to cheer up-scare, command good-prevent evil, freedom-of attachment, and firm-soft (Wigati, 2019: 307).

Gus Dur's structural da'wah tactic with procedural techniques for forming laws and regulations governing Islamic da'wah is to issue policies in the form of legislation to convey da'wah messages with the style or characteristic of Gus Dur's thinking, which becomes his character or identity. The main characteristics or things that become the central values of Gus Dur's struggle are the nine values of monotheism, humanity, justice, equality, liberation, simplicity, brotherhood, chivalry, and local wisdom. Gus Dur's tactics in shaping policy products, both general and da'wah policies, appear to be by prioritizing the contents of the nine central values.

\section{CONCLUSION}

Based on the discussion of this research, it can be concluded as follows: Abdurrahman Wahid or Gus Dur's structural da'wah activities in 19992001 with the position of power as President of the Republic of Indonesia, among others, made da'wah policies. One form of Gus Dur's da'wah policy is legislation in the form of laws, government regulations instead of laws, government regulations, presidential decrees, and presidential instructions.

The da'wah messages conveyed by Gus Dur through the legislation included the themes of Muslim worship, Human Rights (HAM), separatism, and corruption. First, Muslim worship was also regulated by President Gus Dur, namely the worship of zakat (Keppres 8/2001) and hajj (Keppres 97/2000, Keppres 22/2001). Second, related to human rights, Gus Dur tried to take action against human rights violations experienced by children (UU 1/2000, Presidential Decree 12/2001), women (Inpres 9/2000), minority groups, and discrimination such as victims of $G 30$ 
S/PKI (Inpres 1 /2000), ethnic Chinese (Keppres 6/2000), and groups of banned organizations (Keppres 69/2000). Third, the issue of separatism which has created conflicts, such as what happened in Aceh (Keppres 27/2000, Keppres 75/2000) and East Timor (Keppres 28/2000, Keppres $47 / 2000$ ), has also become an area of Gus Dur's da'wah with his media policies. Fourth, the corruption case, an act of theft, attempted to crush Gus Dur by involving the community directly (PP 19/2000, PP 71/2000).

\section{REFERENCES}

Abdullah, (2018). Ilmu Dakwah, Kajian Ontologi, Epistemologi, Aksiologi, dan Aplikasi Dakwah. Depok: Rajawali Pers.

Amin, N. (2007). Kiai Politik (Studi Terhadap Orientasi dan Implikasi Peran Ganda Kiai di Kabupaten Jepara). Laporan penelitian Dosen LAIN Walisongo Seri 2.

Arifuddin, A., \& Muzammil, S.A. (2020). Strategi Komunikasi Dakwah Struktural Kesultanan Kadriyah di Pontianak, Wasilatuna: Jurnal Komunikasi dan Penyiaran Islam, 3(2). https://garuda.kemdikbud.go.id/documents/detail/2316834.

Assiba'i, M. (1997). Sari Sejarah \& Perjuangan Rasulullab saw., terj. Nabhan Husein. Jakarta: Media Dakwah.

Aziz, M. A. (2016). Ilmu Dakwah (Edisi Revisi). Jakarta: Kencana.

Barton, G. (2011). Biografi Gus Dur, The Authorized Biography of Abdurrahman Wahid. Terj. Lie Hua. Yogyakarta: LkiS.

Calhoun, C. (1997). Nationalism. Buckinghum: Open University Press.

Creswell, J. W. (2014). Research Design: Qualitative, Quantitative, and Mixed Methods Approaches. United States: SAGE Publications.

Dye, T. R. (2014). Understanding Public Policy. United States: Pearson.

Farhan. (2014). Bahasa Dakwah Struktural dan Kultural Da'i dalam Perspektif Dramaturgi, At-Turas, 1(2), 268-288. DOI: https://doi.org/10.33650/at-turas.v1i2.162.

Fatimah, S. (2009). Dakwah Struktural (Studi Kasus Perjanjian Hudaibiyah), Jurnal Dakwah Media Komunikasi Dakwah, 10(1), 67-84. http://ejournal.uinsuka.ac.id/dakwah/jurnaldakwah/article/view/415

Huda, M. M. (2020). Metode Dakwah-Politik Kiai Ahmad Fauzan di Kabupaten Jepara, Jurnal Dakwah, 21(2), 141-154. http:/ / ejournal.uinsuka.ac.id/dakwah/jurnaldakwah/article/view/1869/1378. 
Ilaihi, W., \& Hefni, H. (2007). Pengantar Sejarah Dakwah. Jakarta: Kencana. Ketetapan Majelis Permusyawaratan Rakyat Nomor III/MPR/2000, Sumber Hukum dan Tata Urutan Peraturan Perundang-undangan, Pasal 3 Ayat (6).

Kusnawan, A., \& Rustandi, R. (2021). Menemukan Moderasi Beragama dalam Kaderisasi Dakwah: Kajian pada Pemuda Persatuan Islam Jawa Barat, NALAR: Jurnal Peradaban dan Pemikiran Islam, 5(1), 4161. DOI: 10.23971/njppi.v5i1.2900.

Mahfud, M. MD. (2015). Kata Pengantar dalam Ulama dan Politik, Nalar Politik Kebangsaan Majelis Ulama Indonesia (MUI) oleh Bahrul Ulum. Yogyakarta: Pustaka Pelajar.

Muslim, I. (1996). Sahịh Muslim (Juz Awwal). Beirut: Dār al-Kutub al'Ilmiyyah.

Pimay, A. (2006). Metodologi Dakwah. Semarang: RaSAIL.

Rasyidah. (2017). Dakwah Struktural Pakaian Muslimah di Kelantan Malaysia, Takammul: Jurnal Studi Gender dan Islam serta Perlindungan Anak, 6(1), 1-27. DOI: http://dx.doi.org/10.22373/takammul.v6i1.1585.

Rifai, M. (2017). Ensiklopedi Presiden Republik Indonesia: Abdurrabman Wabid. Jogjakarta: Ar-Ruzz Media.

Riyadi, A. (2014). Formulasi Model Dakwah Pengembangan Masyarakat Islam, Jurnal An-Nida Jurnal Komunikasi Islam, 6(2), 111-119. https: / / ejournal.unisnu.ac.id/JKIN/article/view/226/393

Riyadi, A., \& Wigati, Y. I. (2020). Komunikasi Interpersonal Komunitas Pelita dalam Membangun Toleransi Beragama, Jurnal Komunikasi Islam, 10(1), 147-172. http://jki.uinsby.ac.id/index.php/jki/article/view/237

Riyadi, A., Priyangga, Z. G., \& Mustolehudin. (2021). Dakwah Islam dan Nasionalisme: Studi Kasus Dakwah Kebangsaan A.R. Baswedan, Jurnal Dakwah Risalah, 32(1), 1-19. http://ejournal.uinsuska.ac.id/index.php/risalah/article/view/12288

Rosidi. (2013). Dakwah Multikultural di Indonesia, Studi Pemikiran dan Gerakan Dakwah Abdurrahman Wahid, Jurnal Analisis: Jurnal Studi Islam, 13(2). http://ejournal.radenintan.ac.id/index.php/analisis/article/view/7 08.

Rustandi, R., \& Hanifah, H. (2019). Dinamika Dakwah Komunitas Remaja Islam di Kecamatan Pangalengan, ANID A (Aktualisasi Nuansa Ilmu 
Dakwab), 19(2), 199-224. DOI :10.15575/anida.v19i2.7540.

Rustandi, R., \& Sahidin, S. (2019). Analisis Historis Manajemen Dakwah Rosulullah Saw dalam Piagam Madinah, Tamaddun: Jurnal Sejarah dan Kebudayaan Islam, 7(2), 362-387.

DOI: $10.24235 /$ tamaddun.v7i2.5503.g2562.

Sekulic, D., Massey, G., and Hodson, R. (2006). Ethnic Intolerance and Ethnic Conflict in the Dissolution of Yugoslavia, Ethnic and Racial Studies, 29(5), 797-827.

Soeprapto, M. F. I. (2002). Ilmu Perundang-undangan (Dasar-Dasar dan Pembentukannya). Yogyakarta: Kanisus.

Soeprapto, M. F. I. (2005). “Apa Beda Keppres-Perpres-Inpres?”. HU Kompas, diakses pada 14 Juli 2005.

Subandi, B. (2019). Nasionalisme Relijius sebagai Strategi Dakwah Struktural, Proceeding of International Conference on Da'wa and Communication, 1(1), 224-234.

Sukayat, T. (2015). Internalisasi Nilai Islam melalui Kebijakan Publik (Studi terhadap Dakwah Struktural Program Bandung Agamis), Jurnal Dakwah: Media Komunikasi dan Dakwah, 16(1), 79-102. http://ejournal.uinsuka.ac.id/dakwah/jurnaldakwah/article/view/1063/935.

Sulthon, M. (2003). Menjawab Tantangan Zaman, Desain Ilmu Dakwah, Kajian Ontologis, Epistemologis, dan Aksiologis. Yogyakarta: Pustaka Pelajar.

Syahruddin. (2020). Kontribusi Dakwah Struktural dan Dakwah Kultural dalam Pembangunan Kota Palopo, Lentera, 4(1), 61-80. https://journal.uinsi.ac.id/index.php/lentera/article/view/2050/10 91.

Taufani. (2018). Pemikiran Pluralisme Gusdur, Jurnal Tabligh, 19(2), 198217. http://journal.uinalauddin.ac.id/index.php/tabligh/article/view/7475/6113.

Undang-Undang Nomor 15 Tahun 2019, Perubahan atas Undang-Undang Nomor 12 Tahun 2011 tentang Pembentukan Peraturan Perundangundangan, Pasal 1, Angka 3.

Undang-Undang Nomor 15 Tahun 2019, Perubahan atas Undang-Undang Nomor 12 Tahun 2011 tentang Pembentukan Peraturan Perundangundangan, Pasal 1, Angka 4.

Undang-Undang Nomor 15 Tahun 2019, Perubahan atas Undang-Undang Nomor 12 Tahun 2011 tentang Pembentukan Peraturan Perundangundangan, Pasal 52. 
Undang-Undang Nomor 15 Tahun 2019, Perubahan atas Undang-Undang Nomor 12 Tahun 2011 tentang Pembentukan Peraturan Perundangundangan, Pasal 1, Angka 5.

Wahid, A. (1999). Mengurai Hubungan Agama dan Negara, ed. Kacung Marijan dan Ma'mun Murod Al-Brebesy. Jakarta: Grasindo.

Wahid, A. (2006). Islamku Islam Anda Islam Kita Agama Masyarakat Negara Demokrasi. Jakarta: The Wahid Institute.

Wahid, A. (2007). Islam Kosmopolitan Nilai-Nilai Indonesia, Tranformasi Nasional dan Kebudayaan. Jakarta: The Wahid Institute.

Wigati, Y. I., \& Riyadi, A. (2019). Aisyah RA's Interpersonal Communication Model in Sulaiman An-Nadawi's book 'Aisyah', Ilmu Dakwah: Academic Journal for Homiletic Studies, 13(2), 305-328. https://journal.uinsgd.ac.id/index.php/idajhs/article/view/6204. 
